\title{
A Knowledge-based Typology of University Spin-offs in the Context of Regional Economic Development
}

\author{
Harald Bathelt, Dieter F. Kogler \& Andrew K. Munro
}

\begin{abstract}
Version Post-print/accepted manuscript
Citation Bathelt, H., Kogler, D. F., \& Munro, A. K. (2010). A knowledge-based (published version) typology of university spin-offs in the context of regional economic development. Technovation, 30(9), 519-532.

Copyright / License (C) 2010. This manuscript version is made available under the CC-BYNC-ND 4.0 license.

http://creativecommons.org/licenses/by-nc-nd/4.0/

Publisher's Statement The version of record [Bathelt, H., Kogler, D. F., \& Munro, A. K. (2010). A knowledge-based typology of university spin-offs in the context of regional economic development. Technovation, 30(9), 519-532.] is available online at:

http://www.sciencedirect.com/science/article/pii/S0166497210000519 [doi:10.1016/j.technovation.2010.04.003]
\end{abstract}

How to cite TSpace items

Always cite the published version, so the author(s) will receive recognition through services that track citation counts, e.g. Scopus. If you need to cite the page number of the TSpace version (original manuscript or accepted manuscript) because you cannot access the published version, then cite the TSpace version in addition to the published version using the permanent URI (handle) found on the record page. 


\section{A knowledge-based typology of university spin-offs in the context of regional economic development}

by

\section{Harald Bathelt}

University of Toronto, Department of Political Science and Department of Geography and Program in Planning, Sidney Smith Hall, 100 St. George Street, Toronto ON M5S 3G3, Canada, E-mail: harald.bathelt@utoronto.ca, URL: http://www.harald-bathelt.com

\section{Dieter F. Kogler}

Martin Prosperity Institute, Joseph L. Rotman School of Management, 101 College Street, University of Toronto, Toronto, ON M5G 1L7, Canada, E-mail: dieter.kogler@utoronto.ca

\section{Andrew K. Munro}

University of Toronto, Institute for the History and Philosophy of Science and Technology, Victoria College, 91 Charles Street West, Toronto ON M5S 1K7, E-mail: andrew.munro@utoronto.ca

Paper to re-submitted to 


\title{
A knowledge-based typology of university spin-offs in the context of regional economic development
}

\begin{abstract}
Drawing on the literature pertaining to the role universities play in promoting technology transfer, this paper develops an insightful conceptualization of spin-off processes, and applies it to a current regional case study. The suggested typology of university spin-off/start-up firms is based on several variables, including the type of university sponsorship, university involvement in firm formation, the character of knowledge applied, and co-localization of the founders. The empirical case study is used to demonstrate the usefulness of this approach in analyzing spin-off firms, and their dynamics. The study is based on interviews conducted with university spin-offs/start-ups in the information technology (IT) sector located in the Kitchener and Guelph metropolitan areas. This region, which is home to the University of Waterloo - one of Canada's premier science and technology universities -, has experienced an impetus of spinoff processes originating from university research dating back to the 1970s.

The results of our analysis expose several trends: Sponsored spin-offs are largely the result of particular university research projects, and apply specific knowledge inputs in the development of their initial core technology. Unsponsored spin-offs, which find their foundation in decentralized idea development outside of the university setting, almost entirely rely on generic broad knowledge bases for the development of innovative products and services, which have enabled the firm-formation process. Overall, it is surprising that even firms that have received some form of university support described the role the University of Waterloo had in their start-up process as marginal. The dynamic research approach applied in this study, which outlines the university's changing role over time and the regional dynamics associated with spinoff firms, further demonstrates the potential of our typology. As such, our typology of university-related start-up/spin-off firms is designed to support studies concerned with the wider impact of universities on technology transfer and regional development.
\end{abstract}

Keywords: University spin-offs, university-related start-ups, technology transfer, regional innovation, University of Waterloo

JEL Classifications: D21, D23, M13, M15, O18 


\section{Introduction}

In the social science literature, the advantages knowledge-based, technology-intensive firms can accrue from being in close proximity to a university have been widely recognized (Nelson 1959; Arrow 1962). It is believed that high-tech ventures derive significant benefits from localized knowledge spillovers emanating from the two common tasks performed by universities; i.e., basic research and human capital creation (Audretsch et al. 2005). While these knowledge inputs are appealing to firms, access to these inputs appears to depend on the spatial proximity to a particular university (Fujita and Thisse 1996; Fischer and Varga 2003). It was not until the late 1960s, when new information technology (IT) industries emerged, that scholars began to scrutinize the technology transfer mechanisms that led to the direct commercialization of university research through firm formation (Landström 2005).

The seminal works of Roberts (1968), who examined spin-off processes from MIT along Boston's Route 128, and Cooper (1971), who studied spin-off phenomena in Silicon Valley, are especially notable in this regard. It was the institutional and structural change that began in the 1980s (such as the passage of the Bayh-Dole Act in the US) and increased labor mobility, along with a shift towards more flexible modes of production and venture capital financing, that propelled research efforts concerning university entrepreneurship and technology-based growth (see Rothaermel et al. 2007).

University spin-off firms, also commonly called 'university spin-outs' or 'research related start-up ventures', are acknowledged in the literature as one of the key drivers of economic change and growth (Bercovitz and Feldman 2006). Originally a phenomenon thought to be specific to North America, today most advanced national economies strive to generate economic wealth by exploiting and diffusing public research by means of university spin-offs (Clarysse et al. 2005). In many cases, however, such endeavors have had limited success (Callan 2001). Surprisingly, much of the social science literature does not provide a clear-cut definition of the actual university spin-off phenomenon, despite a rapidly growing number of empirical and theoretical studies that span across multiple disciplines (Pirnay et al. 2003). As a consequence, the term 'university spin-off' frequently remains a vaguely defined concept, notwithstanding the 
apparent impact of such firms on the development of high-tech industries (Steffensen et al. 2000). Mustar et al. (2006: 290) conclude in their review that there is "an important gap in our comprehensive understanding of the diversity of RRSOs" (research-based spin-offs).

It appears that this lack of clarity is related to the inherent heterogeneous nature of university spin-off processes, combined with the plurality of research methods applied to study them. This not only poses problems in comparing empirical studies, as researchers potentially present different realities under a common heading, but more importantly, it also obscures our understanding of the underlying processes that drive regional innovation, which, in turn, limits the policy relevance of this type of research (Mustar et al. 2006). Furthermore, spatial considerations, beyond the actual co-location of spin-off ventures and universities, in most cases are not incorporated into the research design, despite the widespread agreement that university spin-off processes support, and sometimes essentially influence, regional economic growth. In our view, it is not desirable to construct a restrictive definition of university spin-off firms by reducing the group of actors and institutions included in the research framework, as this may eliminate important interactive processes that were stimulated or shaped by local universities from the analysis. Instead, the development of a multi-faceted typology of university spin-off firms, which takes into account the heterogeneous nature of such ventures and the spatial context in which they occur, is, in our perspective, a fruitful approach to elucidating and streamlining the complex findings found in the literature, and their diverse theoretical and empirical foundations (see, especially, Pirnay et al. 2003).

Drawing on the literature pertaining to the role universities play in promoting technology transfer, this paper aims to develop a spin-off typology that emphasizes a knowledge perspective, and links the spin-off phenomenon to regional development in a dynamic perspective. In particular, the objective of this paper is to discuss and define the university spin-off phenomenon in a regional context, and to suggest a taxonomy of spinoffs/start-ups based on several variables, including the type of university sponsorship, university involvement in firm formation, the type of university knowledge applied, and co-localization of the founders. We use the empirical findings from a recent regional case study to demonstrate the usefulness of this approach in classifying university-related start-ups/spin-offs; the genesis of these firms is of particular interest to this research. The 
start-up configuration is expected to be an indicator of future development prospects in terms of growth trajectories, and the potential wider regional economic impact these firms will project. Through the analysis of these varying configurations, we intend to find predictive patterns, which subsequently allow for the development of efficient policy programs.

The empirical evidence utilized in our study is derived from 18 semi-structured interviews that were conducted in 2007 and 2008 with university spin-off/start-up firms located in the Kitchener and Guelph metropolitan areas, about $100 \mathrm{~km}$ west of Toronto, Canada. ${ }^{1}$ This region was chosen as a case study for our research, because it has experienced an impetus of spin-off processes originating from university research since the 1970s, which is unusual in the context of Canadian universities, and has subsequently been widely publicized. Similar to the findings of Mustar et al. (2006), that researchbased spin-offs have become an important aspect of the technology transfer process, it is often suggested that regional growth and modernization in the Kitchener and Guelph metropolitan areas have been triggered by IT-related university spin-off activities (e.g. Bramwell et al. 2008). In particular, based on the activities of the University of Waterloo, numerous IT firms, such as Dalsa, Open Text, Research in Motion (RIM), Sybase, and Waterloo Maple, have been successfully launched. They have established a growing technology base in the region (Bathelt and Hecht 1990; Bathelt 1991; Parker 2001; Bramwell et al. 2008), which has led us to focus specifically on the role of IT spin-offs in the present research.

While we are interested in how the university spin-off firms in our sample fit into the various categories developed in our typology, and whether the categories allow us to draw conclusions regarding the firms' collective development potential, particular attention will be given to the university's role at the time of firm formation and how this has changed over time. Our paper is thus structured as follows: In section 2 we review some of the existing literature concerning university spin-off firms, with a focus on many of the critical issues identified in this stream of research. Based on these findings, we propose a typology of university spin-offs and university-related start-ups, which forms

\footnotetext{
${ }^{1}$ In media reports, these municipalities are often referred to as the Waterloo region, in part because of the role of the University of Waterloo as a regional driver of technologies, provider of highquality technical skills, and generator of start-up firms.
} 
the foundation for our empirical investigation. Section 3 discusses the research approach and methodology applied, and in section 4, we examine IT-based university-related startups/spin-offs in the Kitchener and Guelph metropolitan areas through the lens of our proposed typology. Section 5 summarizes the main findings and draws conclusions.

\section{The university spin-off research framework}

The significance of university spin-off and start-up ventures as a technology transfer mechanism for generating and sustaining regional economic growth and competitiveness is widely acknowledged (Rogers 1986; Etzkowitz et al. 2000; Wright et al. 2004). Nonetheless, considerable differences exist between the various interpretations used by scholars to describe spin-off phenomena. This can easily create confusion as a study by Pirnay et al. (2003) exemplifies. In reviewing the literature concerning MIT spin-offs in the Boston region, they found studies that identified rather different start-up rates from MIT. ${ }^{2}$ Pirnay et al. (2003: 355) conclude that "[a]11 these estimations are supposedly accurate but probably rely on different definitions of [university spin-offs], which are not explicitly clarified by the authors." This demonstrates that there is a need to generate a coherent typology and stylized facts that will lead to the development of a policy-relevant theory regarding university spin-offs (an issue that is also emphasized by Mustar et al. 2006), and their impact on local economic development. It is only recently that conceptual studies have identified the differences in existing definitions, and suggested more precise and comprehensive taxonomies of university spin-off/start-up firms (Nicolaou and Birley 2003; Pirnay et al. 2003; Mustar et al. 2006; Djokovic and Souitaris 2008). In the following section, we explore some of the critical issues outlined in this context, and advance a novel typology related to these findings.

\subsection{Variations in existing university spin-offs concepts}

Although a more robust differentiation between technology or research-based start-up ventures and university spin-offs has been discussed by Djokovic and Souitaris (2008),

${ }^{2}$ Similar variations occur when looking through reports on spin-off activities related to the University of Waterloo. 
studies continue to investigate different forms of start-up and spin-off processes under the same label. This is, in most cases, justified by the argument that the respective firms share common characteristics and face similar difficulties in establishing market legitimacy and mobilizing their growth potential (Zahra et al. 2007). University spin-offs, however, differ significantly from other high-tech start-ups as they face two fundamental obstacles when they are initially launched (Vohora et al. 2004). First, unlike their counterparts, which spin off from other businesses in the private sector, university spinoffs originate from a non-commercial environment. The processes that transform an academic idea into a market-ready product or process innovation require resources and skills that most universities and academic entrepreneurs lack. Second, unlike in the private sector, the objectives of the various stakeholders involved in the start-up phase of a university spin-off, such as the university, the academic inventor, the management team, and the venture capitalist, might be guided by different motivations, which - in the worst case - may be conflicting (Boardman and Ponomariov 2009), thus limiting the chances that these businesses will succeed beyond the initial start-up phase (McAdam and McAdam 2008).

Furthermore, university spin-off firms also encounter obstacles in terms of achieving reliability and accountability, which couldhinder market legitimacy (Pries and Guild 2007). Corporate spin-offs are often acknowledged in the context of their parent organizations and their reputation. Attention drawn to the new venture through this avenue thus potentially gives it credibility beyond its actual capabilities. This may not only be reflected in sales figures, but also in the ability to attract talent, and engage in collaborations with other businesses, as well as in the establishment of a positive image in the media, all of which increase the chances of initial survival and subsequent growth (Stuart et al. 1999). In reality, many university spin-offs initially lack such associations. They have to rely on the reputation of their parent university, and perhaps its track record in generating successful spin-off firms. These arguments resonate well with conceptualizations of organizational ecologists in recognizing the importance of establishing legitimacy in order to raise the chance of survival and better performance (Stinchcombe 1965; Hannan and Freeman 1984).

Some of the distinctive criteria that help distinguish university spin-offs from a broader category of technology start-ups include: the origin of the firm's core technology, 
the current or former affiliation of the founding member(s) with a particular parent organization, and the sources of funding used to start up the firm, all of which are in some form linked to a university. The prominent and most decisive condition that seems to qualify a new venture as a university spin-off appears to be the origin of the innovative product or process that serves as the main revenue source. This is explicitly reflected in the definition of university spin-offs by Pirnay et al. (2003: 356). Here, university spinoffs are "new firms created to exploit commercially some knowledge, technology or research results developed within a university". ${ }^{3}$

Firm formation constitutes the main outcome in the establishment of a spin-off, while the transfer of an innovation from the university to the market place represents the main element in the process (Hayter 1997; Bercovitz and Feldman 2006). Both components are common to most definitions but, in terms of what the actual transfer consists of, vary considerably. Some defintions account only for intellectual property, such as patents, licenses, etc. (DiGregorio and Shane 2003), whereas others also include innovations even if they only exist in a non-codified form (Pirnay et al. 2003). Similarly, some definitions consider a new venture to be a university spin-off when the technology transfer is accompanied by a faculty member of the involved university (Smilor et al. 1990), while others adopt a broader understanding that does not necessarily include a transfer of human capital from the parent organization (Nicolaou and Birley 2003).

In addition to the multitude of definitions, university spin-off firms are often investigated from one particular perspective. Mustar et al. (2006) identify three common perspectives in their comprehensive survey of the literature: the resource-based, the business-model, and the institutional perspective.

1. The evaluation of the start-up phase and early-stage development of a university spin-off inevitably leads to an assessment of the resources that enable the formation of the new business. In resource-based analyses, four broad resource categories are commonly recognized: technological, social, human, and financial resources (Mustar et al. 2006). Each of these resources constitutes an asset that is either owned or controlled by the new venture, and that has the potential to

\footnotetext{
${ }^{3}$ In extending this understanding, our definition of university spin-offs emphasizes that universities are not only technical but also social spaces that connect individuals and bring potential founders together.
} 
considerably influence its growth. Additionally, the organizational capabilities and the institutional setting in which a business operates need to be considered.

2. The business model approach in the analysis of research-based spin-offs has only recently become a subject of investigation (Bower 2003), and relates to a firm's value proposition, market segment, position in the value chain, cost structure, and profit potential (Chesbrough and Rosenbloom 2002). According to Mustar et al. (2006), distinctions can be made between studies focusing on the actual economic activity carried out (Chiesa and Piccaluga 2000), the process of transforming knowledge or prior experience into economic value (Aggarwal and Bayus 2002; Druilhe and Garnsey 2004), and the actual growth orientation of the new venture (Saxenian 1994; Autio and Lumme 1998).

3. The institutional context, in which a venture is founded and operates, is another perspective that is frequently explored in the university spin-off literature; i.e., the specific setting of the university which has its own culture, norms and rules (Moray and Clarysse 2005). Of particular interest is the degree of dependence or reliance of a university spin-off on regulations regarding intellectual property rights, transfer policies, or start-up help (Roberts 1991). The intensity of these relationships is, in turn, used to differentiate between spin-off firms that have strong linkages and depend heavily on the university's positive attitude towards technology commercialization, and start-ups that are only loosely connected with a university institute, and therefore are not specifically influenced by its institutional policies. Few studies exist that make a distinction between researchbased spin-offs that receive direct support from a university, and those start-ups which occur spontaneously, largely as a result of individual endeavors (Steffensen et al. 2000). As discussed in the next section, we advance this latter distinction in our typology.

Often, studies of university spin-off processes are static, only providing a snapshot of the processes that lead to spin-off formations. They often pay relatively little attention to the nature of knowledge linkages in a regional context. Furthermore, many studies tend to neglect the development of the regional population of spin-offs and their development problems over time. One exception is a study conducted by Ndonzuau et al. (2002: 282), who identify four stages that explain the process through which academic research results 
are commercialized. These are: the generation of business ideas from research, the finalization of new venture projects out of ideas, the launching of spin-off firms from projects, and the creation of economic value by spin-off firms. Each of these stages describes a specific function inherent to global value creation from university research. Similarly, Vohora et al. (2004) identify multiple distinct phases in the evolution of university spin-offs, yet do not have a specific regional knowledge creation perspective in their study.

A dynamic research perspective that focuses on the nature of knowledge flows, in contrast to a static study of the spin-off phenomenon, is preferable as it allows for the examination of the dynamic processes university spin-offs/start-ups experience during different stages of their life-cycle. For example, this type of approach would enable us to capture the changing relationship between a university spin-off and its parent organization. In terms of initial knowledge inputs that result in innovation, a university spin-off/start-up is expected to rely on strong ties with its parent university. At a later stage, however, once the spin-off is established, customer or supplier relationships may provide equally or more important innovation impulses (Fontes 2005). ${ }^{4}$ By employing a dynamic perspective in the next section, we attempt to develop a comprehensive typology of university-related start-up/spin-off firms.

\subsection{Establishing a typology of university spin-offs and university-related start-ups in regional context}

Following the above review of the university spin-off literature, it is apparent that there is still a need to explore how to best define and differentiate university spin-offs, and their impact on knowledge flows and economic development within a region. This is not a trivial question, as emphasized by Mustar et al. (2006), since there is not a widely accepted definition, despite thoughtful attempts in the past to develop more rigorous typologies of university spin-offs (Pirnay et al. 2003). The understanding of what a university spin-off is can vary significantly between different empirical studies:

\footnotetext{
${ }^{4}$ This relates to the distinction between the stages of spin-off creation and spin-off development (Mustar et al. 2006).
} 
On one end of the spectrum, university spin-offs are defined as activities that develop directly from university research. In such studies, the spin-off process involves both a direct transfer of personnel and novel scientific or technical concepts to the private sector (Smilor et al. 1990; Rappert et al. 1999). Often, the university is, at least in part, the owner of the intellectual property rights to the new product developed by its staff through research activities. Although variations exist between and within countries (Rasmussen et al. 2006), this is commonly found amongst Canadian universities (Rasmussen 2008). The University of Waterloo, however, on which our empirical findings are focused, enacted a very different policy during the 1960s, whereby the developer or inventor of intellectual property generally remains the owner of that property (Bathelt and Hecht 1990; Bramwell and Wolfe 2008). Even though there may be contexts when such a narrowly-defined concept of university spin-offs can purposefully be applied, we found that this was not sufficient for our study, as it only covers a portion of the varying technological and economic impacts a university has on its regional economy.

On the other extreme, some studies are much more ambiguous, and more inclusive in their use of the spin-off term. For instance, some literature considers every firm as a university spin-off, so long as it is founded by a university graduate. This definition, in turn, is also problematic because it implies that the majority of all existing firms should be classified as university spin-offs, based on the premise that they were started by someone with a university degree (for an overview, see Garvin 1983; Mossig 2000). While this latter definition seems to reflect the University of Waterloo's view of spin-off firms in the 1980s, its Technology Transfer Office (now: the Intellectual Property Management Group) has adopted a different perspective that is more exclusive in its definition.

We concur with Pirnay et al. (2003: 355) that the "continued adoption of a loose definition for such a key element could harm future research". In the present study, we establish a comprehensive typology of university spin-off and university-related start-up firms, building upon the literature reviewed above. We define a university start-up/spinoff as a firm which draws upon knowledge that is produced or circulated at the university, in which the founders have met or become associated in the context of a university, and where the business opportunities are an outcome of the university's existing areas of 
competence in research and teaching. In line with McQueen and Wallmark (1982), we assume that there is a direct transfer from the university to new firms and/or a direct link between the university and the founder(s) that create the opportunity to start up a new venture in a specific technology field (see, also, Pirnay et al. 2003). Moreover, we emphasize the regional significance when analyzing the role of knowledge linkages and how they change over time. What differentiates our typology from existing ones is that it emphasizes the role university spin-offs play in regional economic development by focusing on the collective impacts of these firms. ${ }^{5}$ Furthermore, it attempts to adopt a dynamic perspective.

Table 1 portrays a classification of spin-offs/start-ups according to university sponsorship and university involvement. This distinction allows us to differentiate firms according to how "close" their start-up process is to the university's core research competencies. With respect to the sponsorship criterion, sponsored spin-offs are viewed as firms that are established with active support and approval of the university. Only in rare situations does this support, however, involve direct money transfers. Instead, sponsorship typically relates to training and support in the management of the start-up phase. Sometimes, this includes granting preliminary office/research space, and the use of university facilities such as libraries and research laboratories at a lower than market rate. Support can also entail the university buying a new firm's products instead of established goods and services from existing firms. This distinction draws on studies that analyze the strength and character of university-spin-off linkages (e.g. Smilor et al. 1990; DiGregorio and Shane 2003).

It is important to note that university spin-offs can also be unsponsored. ${ }^{6}$ An example of this category would be if a researcher, previously employed by a university, establishes a firm that is legally acceptable, but is not sponsored by the university. Alternatively, although possibly quite rarely, a firm might spin off despite the

\footnotetext{
${ }^{5}$ Very few of the studies analyzed in recent literature reviews by Pirnay et al. (2003) and Mustar et al. (2006) are carried out with a specific regional perspective which focuses on the regional impact of university spin-offs. We suggest that such a spatial focus is instrumental from a regional policy perspective.

${ }^{6}$ The distinction between sponsored and unsponsored university spin-offs takes into account Steffensen et al.' (2000) differentiation of spontaneously occurring vs. planned new ventures. In contrast with Pirnay et al.'s (2003) categorization, our typology therefore includes firms which result from emergent processes, rather than just intended spin-offs.
} 
university's objections. The latter could occur in a university-industry joint venture project in which the private partner establishes a firm that utilizes knowledge that was primarily developed in the university. Such a situation may not occur frequently, but if such unintended knowledge transfers have occurred in the past, a university might be less likely to continue collaborating with private-sector firms in research projects. In most cases, however, new ventures that fall into the category of unsponsored spin-offs are likely in line with the general expectations put forward by a university's technology transfer policies.

Insert Table 1 about here

In terms of university involvement, we differentiate between three types of ventures (see, also, Mustar et al. 2006): (i) spin-offs from university research that are based on intellectual property developed at the university, (ii) spin-offs which result from university-industry joint ventures, (iii) start-ups resulting from decentralized individual or collective ideas developed at the university, unrelated to the university's research projects (Table 1). This categorization makes use of Roberts' (1991) distinction between spin-offs and start-ups. ${ }^{7}$ The latter group involves firms which are started up by former graduate or undergraduate students after they finish school (Steffensen et al. 2000). These students could have met while studying in the same or a related field, having developed a business idea from their joint classroom experience. We refer to these firms as university-related start-ups, as opposed to university spin-offs from research projects. We strongly believe that it is important to include these firms, as it is unlikely that they would exist if the university had not provided the social space for the founders to align and develop their business ideas, while concurrently benefiting from experiences of other start-ups and spin-offs. It is, however, very difficult to study this group of spin-off firms as there is no natural data base from which to draw information.

\footnotetext{
${ }^{7}$ It also correlates with Pirnay et al.'s (2003) differentiation between academic and student spinoffs, which emphasizes that new ventures in a university context are not always founded by researchers who leave their place of work.
} 
In terms of reliability and accountability, university-related start-ups and the spinoffs from pure university research often have minimal market legitimacy in their early stages (Vohora et al. 2004; Pries and Guild 2007). They have to demonstrate that they are competent and able to replicate their structure in order to earn legitimacy in the market (Hannan and Freeman 1984). This process is not routine, and can take an undeterminable amount of time. Firms that belong to this group are less likely to produce high growth levels, than spin-off firms which result from combined university-industry collaboration. The latter firms benefit from existing industry networks and third-party referrals that are passed on to them. Many ventures develop in an evolutionary pattern over a longer time period before being formally started up (for a summary, see Hayter 1997; Stam 2007). If the respective founders manage to establish networks with initial customers, suppliers, investors, and employees in the pre-launch period, they will likely start at a higher level of legitimacy when formally entering the market. As the start-up processes of these firms are often not associated with an actual logistical decision, legitimacy may, to some degree, be strongly focused on the regional market, which in turn may drive a relatively strong initial local orientation. Of course, a lack of legitimacy also makes it more difficult for firms to acquire start-up financing and further investments, despite the existence of venture capital. Founders seem to make up for such problems by mobilizing resources for seed financing from existing social networks, which are often concentrated in their region, such as local banks, family, and friends (e.g. Zook 2002; Kenney and Patton 2005). This partially explains why regional linkages can be stronger in the start-up phase compared to later stages (e.g. Fontes 2005). The sponsored spin-offs in our typology, emanating from university research, are related to the more rigid definitions found in the university spin-off literature, whereas unsponsored spin-offs based on decentralized idea development are situated on the opposite side of the spectrum, referred to here as university-related start-ups (see, also, Pirnay et al. 2003; Mustar et al. 2006). ${ }^{8}$ The categories in between cover a range of other options of university spin-off formations, which capture the multitude of possible constellations that

\footnotetext{
${ }^{8}$ In combination, this allows us to distinguish between organized and more spontaneous spin-offs (Steffensen et al. 2000).
} 
lead to firm formation based on specific university research or the broader university experience of firm founders.

Beyond this classification, we suggest two additional complementary distinctions of university spin-off/start-up activities, which may help us to better understand the focus of the relationships of new firms and the growth potential of these ventures. These distinctions allow us to further differentiate between spin-offs according to the character of university knowledge applied and the pattern of co-location of the founders (Table 2). The pattern of co-location in the start-up period illustrates whether the founders of a firm are associated with the same university (which is, by definition, also the case if there is only one founder), or with different universities in different regions (referred to as nonco-localized start-ups/spin-offs). In the co-localization scenario, firms will likely draw more heavily on regional resources in the start-up stage while, in the case of non-colocalization, when the founders are not from the same regional university/organization, firms may be able to develop wider interregional networks from the very beginning. ${ }^{9}$ Both instances might be indicative of different growth trajectories, one being built around regional limitations, and the other based on wider cross-regional legitimacy. In general, we might expect stronger initial growth and impacts on the regional economy in terms of employment and linkages if a large proportion of the university spin-offs/start-ups can be characterized as belonging to the non-co-localized type.

The second variable applied in Table 2 explores the character of university knowledge that is used for the spin-off/start-up process, similar to what has been suggested by Pirnay et al. (2003). Here, the distinction is made between (i) generic, broader, less specific knowledge which can, for instance, be transmitted in a seminar or lecture, and (ii) specific knowledge related to the competence base of the university that is closely tied to university research (see, also, Hindle and Yencken 2004). ${ }^{10}$ The firms engaged in the use of the latter knowledge segment are expected to coincide to some degree with the group of university spin-offs described in Table 1, while firms in the former category likely correspond more with university-related start-ups. It is anticipated

${ }^{9}$ This takes into account that a spin-off's success depends on the size of its contact network to a range of partners including customer and financial organizations (Mustar 1997).

${ }^{10}$ In contrast with Pirnay et al. (2003), we distinguish between generic and specialized, as opposed to codified and tacit, knowledge assuming that each spin-off draws on a combination of explicit and implicit knowledge. The importance of knowledge is also emphasized by Fontes (2005). 
that co-founders of university spin-offs tend to be co-located prior to the actual firm formation process when drawing on joint research or work experience that is related to the predominant technology sector in a region. This should especially be the case when specific, in particular tacit, knowledge serves as a key asset in the development of innovative products and processes. Nonetheless, we might expect that start-ups/spin-offs that are built on generic knowledge, if successful, will have the potential to also address a broader market over time. In collective terms, this could indicate a large regional growth potential, although the danger might exist that initial technological advantages at the corporate level evaporate through the process of globalization (Maskell and Malmberg 1999).

The two classifications developed above not only allow us to distinguish between different types of spin-offs/start-ups according to their individual growth potential, but, in aggregate terms, enable us to draw conclusions about regional development paths. This could be particularly helpful in a comparative research context, when comparing different regions and/or sectors.

Insert Table 2 about here

\section{Research approach and methodology}

In our empirical research, we have applied this typology to the Kitchener and Guelph metropolitan areas, which host the University of Waterloo - Canada's most well-known university for spin-off firm creation processes. In order to investigate spin-offs and their impact on regional innovation, and in particular to categorize and assess the diversity of various types of university spin-offs, we conducted a largely qualitative study of ITrelated university spin-offs, using semi-structured interviews.

The total population of university spin-offs and university-related start-ups was composed as follows (Table 3): we began with a list of 47 spin-off firms from the University of Waterloo (provided by the university's Intellectual Property Management Group in August 2007), and an additional list of 14 firms where the University of Guelph 
played an active role in the start-up process (provided by the university's Business Development Office in September 2007). Further, we obtained a list of 227 start-up firms, published by PricewaterhouseCoopers (2001a) as a result of a survey that asked firms to identified themselves as being related to the regional universities, on a scale from strongly related ("but-for") to weakly related ("at least in part") (PricewaterhouseCoopers 2001b). ${ }^{11}$ We assessed the firms indicated by the universities as true spin-off firms, since they were closely related to university research. The other firms identified by PricewaterhouseCoopers (2001a) were viewed as university-related start-ups.

Insert Table 3 about here

The majority of spin-off/start-up firms listed in Table 3 belong to either the engineering or IT industry. We decided to focus on IT firms in our study because they likely have a stronger impact on regional innovation, and have often been emphasized as being of key importance for regional growth and modernization in the region (e.g. Bramwell et al. 2008; Bramwell and Wolfe 2008). The aggregate set of 119 IT firms consisted of 25 university spin-offs ${ }^{12}$ and 94 university-related start-ups (Table 3). However, our overall population of regional IT firms was much smaller, and consisted of only 42 firms, due to firm closures, relocations, and mergers. ${ }^{13}$ From this population of 42 firms a sample of 32 firms were contacted, 14 of which were unresponsive or did not agree to an interview. Although this resulted in a seemingly small sample of 18 firms, it is important to note that these firms represent a substantive portion of the IT-related start-up/spin-off

${ }^{11}$ The PricewaterhouseCoopers list is not unproblematic, as we cannot verify its reliability. It is, however, the only list of its type available and was, therefore, a key input to our research.

${ }^{12}$ As the list provided by the University of Guelph contained only 1 IT-related spin-off firm, our analysis focused on University of Waterloo spin-offs.

${ }^{13}$ Prior to the sampling process, we contacted as many of the 119 firms as possible to collect key information such as their business focus, address, firm size, and a potential interview partner. This was a time-intensive process that included verifying information with regional virtual firm directories, the cities' business development offices, as well as several other websites. As a result of this intensive search process, 16 firms $(13 \%)$ could not be found and $36(30 \%)$ were not located within the region. An additional eight firms $(7 \%)$ were acquired by other IT firms on the list, whereas 17 establishments (14\%) were confirmed closed. 
activities of the University of Waterloo (43\%). Additionally, we conducted eight interviews with university technology transfer offices, economic development divisions of the cities, and leading representatives of business organizations. These interviews were conducted for the purpose of triangulation and to get an overview of the overall start-up policies in the region.

Throughout our interviews, we asked open-ended questions about the circumstances under which start-up/spin-off firms were founded, with a particular interest in the role the university and knowledge linkages played in this process. The questions posed in the interviews focused on two main areas of interest: First, we aimed to identify the goals, incentives, and conditions under which the firms were started up, with particular focus on university involvement and sponsorship. Moreover, we inquired about the characteristics of the university knowledge that subsequently helped initiate the start-up process. This set of questions was instrumental in classifying the different spinoff/start-up firms with respect to our typology. The second set of questions focused on material linkages and knowledge flows that developed within the region or with partners in other regions and countries, and how they changed over time. Key characteristics, and the categorization of the firms, according to the typology set out in Tables 1 and 2, are shown in Table 4. The informative results of the interviews are discussed in the next section.

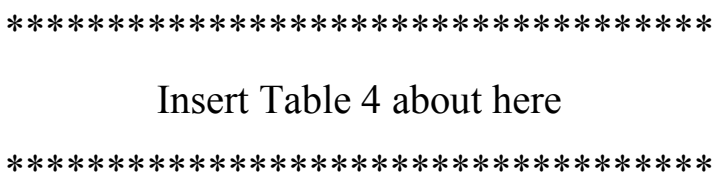

\section{University of Waterloo spin-off processes}

The transformation that has taken place in the Kitchener and Guelph metropolitan areas from an economy based on traditional manufacturing to one with a substantial proportion of IT-related businesses is often attributed to knowledge transfers and growth triggers from university spin-off processes (Communitech 2006; Bramwell et al. 2008). Since the 1970s, numerous university spin-offs were started up in the region. This was related to the foundation of the University of Waterloo in 1959 as a university with an engineering 
focus, allowing members of the university to own patents from university research, as opposed to the common policy whereby the university would remain, at least in part, in possession of the intellectual property rights. Industrial leaders, such as Ira Needles from BF Goodrich, played an important role in structuring the university. They shaped the university's co-operative education (co-op) program and its openness toward private sector collaboration ${ }^{14}$ (Bathelt 1991; Wahl 2007; Bramwell and Wolfe 2008). Compared to other Canadian universities in the post-World War II period, the University of Waterloo not only had a more pronounced focus on establishing university-industry linkages, but also developed a stronger focus on basic and applied research. According to data presented by Niosi (2000), the University of Waterloo was Canada's largest research university in the late 1960s with 533 researchers, representing about a quarter of all researchers at Canadian universities. In comparison, for instance, the University of Toronto had only 256 researchers according to this data set.

By 2007, research at the University of Waterloo had led to the establishment of 47 spin-off firms related to university research, 24 of which were directly related to IT industries (Table 3). The university's initial advantage in fostering spin-off processes, however, apparently decreased over time; as early as the 1990s, observers began speculating that the overall key to economic growth and success in the region was increasingly due to the co-op program and a constant flow of highly-qualified graduates, who found a job in the region's growing technology sectors (Bathelt 1991).

Utilizing the results derived from our interviews, the next section examines some of the university spin-off/start-up processes of IT firms in the region, and categorizes them according to our typology developed above.

\subsection{Setting the sample of IT spin-offs/start-ups into context}

All 18 IT firms in our sample had direct ties to the University of Waterloo: Some of the founders were graduates (18 individuals); others were faculty (seven individuals) or staff members (five individuals). However, the actual role the University of Waterloo played in the foundation of these firms was frequently found to be either minimal or indirect.

\footnotetext{
${ }^{14}$ As part of this, the University of Waterloo received substantial funding from multinational IT firms. It received about 40 million CAD in IT-related funds from IBM and DEC in 1980s - a practice, which continues today through RIM's massive investments into the university's research infrastructure.
} 
This is somewhat surprising as the university is frequently portrayed as the central agent in the rise of regional IT-related developments. ${ }^{15}$ In eight cases (almost $50 \%$ of the total sample), we did not find any active university involvement in the start-up process. The firms were founded using knowledge that had not been sponsored by the university, and the firm formation process was not tied directly to university activities and occurred without university involvement.

In contrast, six of the firms, or $33 \%$, were founded by faculty or staff members based on a core technology that was, at least in part, developed within the university. They fell into our category of firms that were founded through university sponsorship and developed into a spin-off by the university. In four of these cases, the technology was the direct outcome of a university research project, and the University of Waterloo received some sort of compensation for the intellectual property rights, either through the transfer of funds or through shares in the new venture. Essentially, these firms constitute the essence of a spin-off, whereby an informal business unit was removed from its university setting and spun off into a stand-alone business model.

Only three of the 18 firms in the sample were founded following a collaborative project between the university and industry, thus fitting into our category of firms that were established through sponsored research in a joint venture with industry. These classification types and the implications of our results will be discussed in more detail below.

Most of the firms in our sample operate in product markets, rather than technology or problem-solving markets, according to the distinction made by Pries and Guild (2007). The firms we analyzed had an overwhelming software focus, often based on specific mathematical algorithms or software solutions, sometimes complemented by a hardware component. Even the firms that offer a hardware product-line still produce software as an integral part of their product offering. As discussed before, the original list of university spin-offs and university-related start-ups contained a number of firms that had been acquired by other firms, sometimes resulting in the relocation of the original business unit. Typically, the technology and some of the senior management left the region, but the majority of employees were let go or quit in order to remain in the

\footnotetext{
15 The study by Colapinto (2007) also found fewer university-related start-ups than expected, with less than $20 \%$ being closely related to technology transfers from the university.
} 
region. If we consider that the PricewaterhouseCoopers list was just recently established in 2001, this indicates that the spin-off and start-up firms in the region experienced substantial structural changes in their early years. Since their establishment, six firms were acquired, most of them by another larger firm. This typically occurred five to ten years following the foundation of the original venture. Out of these six firms that were acquired, the core business unit remained in four cases part of the main development center for the new firm. In one notable case, a firm was acquired four times by successively larger corporations, but the actual business unit remained almost completely intact, with the same management personnel and the same basic product line. All of these firms were acquired by non-regional players with the goal of adding another product line to their already existing businesses, and also to develop a physical presence in the region.

The spin-off processes common to the Kitchener and Guelph metropolitan areas often did not follow the expected path of intellectual property transfer from a research project at the university to a private spin-off firm started by a faculty member. ${ }^{16}$ Our interviews, as well as media reports and other academic studies of the region's technological development (e.g. Bathelt and Hecht 1990; Bramwell and Wolfe 2008), clearly indicate that the University of Waterloo and the community leaders in the region are very proud of the entrepreneurial output of the university's faculty. One particular aspect, repeatedly emphasized in this context, was the 'inventor-owned' intellectual property policy of the University of Waterloo, which seemingly attracted commerciallyoriented faculty. In media reports, this was frequently recognized as an important contribution to the economic growth in the region. This type of spin-off process, whereby a university-developed research product is commercialized and the firm's initial development stage is aided by the university through either economic support or the use of facilities, however, only occurred in four cases or less than $20 \%$. Again, this ratio was much lower than our expectation, especially considering the general perception of the University of Waterloo's significant role in the generation of spin-off firms.

\footnotetext{
${ }^{16}$ Based on a standardized questionnaire, Xu (2003) estimated that $65 \%$ of all start-ups were based on some sort of knowledge transfer related to the University of Waterloo. Although this result appears optimistic in the light of the interviews conducted in our study, $\mathrm{Xu}$ (2003) also found that the knowledge transfer linkages decreased over time.
} 


\subsection{Unsponsored spin-offs based on decentralized idea development}

Eight firms in our sample, again almost 50\%, fell into the 'decentralized unsponsored' category, this being the most common category amongst the sample. In these cases, the university was not involved in sponsoring the development of the core technologies around which the firms were created. Also, the university did not contribute to the startup process by means of specific knowledge inputs acquired through explicit university research projects. The tie to the University of Waterloo was usually that the founders were trained there, and met while in school (socially or in class), or while working in the region after graduation. In seven of the eight cases in this category, the founders relied on generic, broad knowledge during the development process of their initial products, which they received during their university education. The typical start-up process of these firms involved an initial recognition of an existing market niche that was considered by the founder(s) to be an economic opportunity, combined with the belief that existing capabilities were sufficient to develop a product advanced enough to exploit.

One example of a decentralized and unsponsored start-up process is a small firm that was created by two University of Waterloo students. The two founders were enrolled in the co-operative education program at the University of Waterloo and met during a work term. They were both online game enthusiasts who believed that they could improve their game-play experience by means of a voice-communications software. As a consequence, they began product development and eventually created a voice-over Internet program. The firm was later acquired by a multinational software development firm that took the program and used it as a basis for two of their major products lines. The intellectual property developed by this unsponsored decentralized firm was solely created by the individual founders. They met, conceived, and developed their software off-campus, and received no support from the university.

Another example we found of a venture that falls under this category is a medium-sized software firm that produces file-management and control software for office machines. The two founders initially met when they were working for the same employer (a private firm). At that time, one was in his co-op term, while the other had just completed his co-op term at the firm and was subsequently hired. These two individuals communicated their original business idea, which aimed to address 
shortcomings in the current product offerings of the firm to the owners, but without any success. Consequently, they decided to leave the firm and start their own business utilizing this exact idea to develop their core product; a major US competitor later acquired the firm. The original product is now one of the main product offerings of the amalgamated entities. In this example, the founders both originated from within the region and drew from generic knowledge in the field of software development that they acquired during their time at the university. Our interviewee believed that the university played a role in the development of their firm because of the training they received and the fact that they met while one of the founders was on a co-op term. The interviewee added that the university's approach, namely their emphasis on business opportunities and product development, had been instrumental in the decision to start up a firm.

Common to each case in this category, the university only played an indirect role in the development of the business idea and the subsequent firm formation process, mainly through the supply of the necessary basic technical education, and perhaps by propagating an aptitude for product development and business ideas. Furthermore, the university provided the opportunity for social interaction, either on campus or through its reputable co-op program, which was frequently cited as the initial meeting place for founders. Overall, the significant role these firms play in the region shows that it is important to include spontaneous ventures that are not sponsored by the university (Steffensen et al. 2000).

\subsection{Sponsored spin-offs based on specific university research projects and university-industry joint ventures}

Contrary to the firms in the previous category, sponsored spin-offs, which are established to commercialize innovations that are a direct result from either specific university research projects or university-industry joint ventures, are much closer to the original conceptualization of university spin-offs found in the literature (Smilor et al. 1990; DiGregorio and Shane 2003). Such ventures involve some transfer of tangible or intangible assets from the university to the newly established business. This practice of sponsorship has a long tradition at the University of Waterloo. Volker-Craig, for instance, a producer of computer terminals, an early spin-off founded in 1973, benefited 
tremendously from direct sales of equipment to, and steady support from, the university's computer laboratories. The firm experienced substantial business success in its early years, and employed 185 people in 1980, but this took a downward turn, and by 1988 only six employees were left in the region, and later the firm closed down (Allaby 1984; Black 1988; Bathelt 1991). Today, however, the type of university sponsorship has changed, and is often found to be less direct.

One of the firms in our analysis is a clear example of this change in sponsorship, which is representative of a number of spin-offs found in this category. This software developer, which allowed for the manipulation of symbolic data at a time when other programs were only able to handle numeric data, was founded by the principal university researchers who created this software, and who were themselves studying symbolic mathematics. Despite the product being offered free to the academic community, the overall demand was so high that an individual was required just to keep up with copying floppy disks and filling orders. As a consequence, a full-time staff member had to be hired. The establishment of the firm was more of a decision based on the need to distribute the software to academics, rather than a drive to commercialize the product. Support for the firm was provided by the University of Waterloo in the form of space and office resources. Of key interest however, is that the University of Waterloo's Intellectual Property Management Group was not involved as the technology was not patented. ${ }^{17}$ Moreover, specific business development support was also not provided.

Most interviewees in this category stressed that support from the university in the initial start-up phase mainly consisted of transfers in the form of intangible assets, such as results from specific ongoing university research, which produced a business idea that led to the actual firm formation. The transfer of tangible assets from the university to the newly found firms, such as direct financial support, business advisory, and technology transfer assistance, were not mentioned by our interviewees, and thus were obviously not instrumental in the establishment of the firms.

Spin-off firms that are the result of university-industry joint ventures are similar to those sponsored by university research projects, as they also draw from specific research knowledge generated within the university setting. In these instances, an

\footnotetext{
${ }^{17}$ It should be noted that the other firms in our sample also indicated that this office was not significantly involved in their spin-off or start-up process.
} 
industry partner, which in most cases is an existing business that seeks the expertise of faculty in a particular technology field in order to solve an existing problem or to produce an advanced product, is involved in the initial development of an innovative solution. A well-known regional example of a spin-off firm, which grew out of a joint venture research project with Oxford University Press, is Open Text. The goal of this collaboration was to develop computer-indexing and string-search algorithms for structuring a digital version of the Oxford English Dictionary (Open Text Corporation 2001; Colapinto 2007). While the actual development of an innovative product or process is the intended outcome of such contractual relationships, the establishment of a new business that utilizes the developed technology, or parts of it, is often an unintended by-product.

One example we identified in this category, from the sample of firms we analyzed, initially operated as a medium-sized firm that specializes in software for the visualization of data. This firm was started in the mid 1980s by a then undergraduate student. The student was approached by a firm looking to print plot-files from computer-aided design software on office dot-matrix printers, rather than on the industry-grade flat-bed scanners, which were the only option at the time. The original product was the result of contracted research between the student and the sponsoring firm, with the student receiving ongoing support from his fourth-year research supervisor as part of the professor's obligations to his students. The founder of the firm, at the time still a student, continued to develop the idea after the contract was finished. While still receiving intellectual support from the university, he created a firm that would focus on what was a revolutionary technology field at the time (printing on home and office printers) and has continued to innovate and evolve within the technological frontier ever since. In this particular example, the intellectual property generated, which formed the core technology of the firm, was the result of the research developed under contract between an existing business and the student.

In the two cases of sponsored university-industry joint ventures that were identified, product development and the subsequent firm formation were the outcome of a contract-based research project rather than the direct result of ongoing university research.

All respondents to our survey indicated that the reason they started their firms in the region was that they were already living there. In the instances, where the University 
of Waterloo played a fundamental role in the creation of the core technologies, the relationship between the university and the spin-off firm typically decreased over time. It should be reiterated, however, that only six firms (one third) fell into the category of sponsored spin-offs. In contrast to the majority of firms, two university-sponsored spinoffs remained actively involved in activities at the University of Waterloo. At the time of our interviews, however, neither of the firms received significant inputs into their innovation process from university collaborations. The founder of one well-known software firm noted that "the primary value of these projects is to meet, and get access to, future potential employees" (Interview 13). Firms which were spun off from universityindustry collaboration (three out of 18 firms), be it in a sponsored or unsponsored form, also experienced a decline in their relationship with the university since their establishment. In the case of a larger data and work-flow-management software developer, initial product innovations occurred while the development was still situated within the university. Later relations were classified as "arms length" by one of the founders, who remained a university professor. It was noted that there were still collaborative research projects underway but that "these projects have not been decisive for the firm" (Interview 9).

In all of the cases, the University of Waterloo was of fundamental importance to the establishment of the firms, but this role diminished and, as time passed, the university no longer provided key inputs to the innovation process. Regardless of the initial relationship with the university, it was surprising - given our original expectations - to find that the existing relationship between the University of Waterloo and these firms is weak overall. When the 18 firms were asked to identify the most important organizations supporting their innovative processes, only four (about 20\%) named the University of Waterloo; however, those four firms also identified customers as being equally important. In fact, all of the 18 firms interviewed identified customers as the most important influence for stimulating innovations. As opposed to the radical innovations, specifically based on university-sponsored research that marked the foundations of many of these 
firms, most firms have since shifted their research toward more incremental innovations drawing from ongoing customer relationships. ${ }^{18}$

\subsection{Less frequently encountered types of spin-offs}

The majority of spin-offs/start-ups identified through our sample (14 of 18 firms) fit into one of the previously discussed categories of firm-formation processes. The remaining four cases in our study are examples that fit into one of the categories of unsponsored spin-offs from university research or university-industry joint ventures, and establishments based on university-sponsored decentralized idea development, put forward in our typology. Two firms, despite being situated in the university-based research category, did not receive any form of university sponsorship. In both cases, the founders were involved in the development of technologies within the University of Waterloo's Computer Systems Group, but left the organization with ownership of the intellectual property rights to the technology, which was utilized to establish their own businesses. However, this process was not a formal spin-off from the university with the goal of forming a business unit. Nevertheless, practically the same administrative and technological core was retained even as the physical location shifted, and the same individuals now worked for the firm rather than the university. Both firms required substantial additional development of core technologies to become a viable independent business, and although the founders retained strong social ties with the university, they did not attribute the university with providing ongoing support to the firm or as having any involvement in the development of the business. In one instance, the founder continued to work at the university for another ten years while developing his own business, until the business was sufficiently established and generated a sufficient revenue stream to cover living expenses. Both of these firms are specific examples of our category of unsponsored spin-offs from university research.

One venture in our sample distinctly falls into the segment of unsponsored spinoffs, despite being the result of a university-industry joint venture. Spin-offs from

\footnotetext{
${ }^{18}$ In addition to a noticeable decrease in the number of university spin-offs/start-ups over time, second-generation spin-offs, such as B2B Scene which originated from Open Text, were an infrequent event in the region (see, also, Colapinto 2007).
} 
university-industry collaboration are generally either the product of contract research, or an ancillary development of a research project that was not an intended outcome at the beginning of a proposed project. In this case, the firm is a manufacturer of precision optical-sensing devices, and the core technology was developed as a result of a contract research-and-development project. In the early 1980s, the founder of the firm, who was employed at the university in the Computer Systems Group, had initially created a firm that offered customization of hardware and software that required automation. The university approached this organization to produce an instrument that would allow researchers to measure the three-dimensional grasping-task of a human hand and correlate that against brain activity. The firm and the university worked together closely, with the university team providing the necessary information for the biomedical inputs that the instrument would require in order to sense and to help validate the measurements, while the firm developed the instrument and its control software. The device was put to use in the university's kinesiology lab and showcased at a major international academic conference hosted by the university. Soon after, orders came in for a similar device to be utilized in other research laboratories around the world. This became a key product and a source of cash infusion for the firm. As the market for this product was limited, the firm used the capital from these initial sales to develop two major product lines, one being a sensing device for precision manufacturing, and the second being sensing and robotic hardware and control software for robotic-assisted surgical instrument systems. In our typology, this example, however, is not one of sponsored research because the university research did not form the core technology for the products developed. The sensing devices and the hardware-software interface systems were developed internally by the firm, and the products that became the core offering of the firm, since it moved away from the contract research, utilized key technologies developed out of prior research. The founder primarily drew upon the university's core specific knowledge competencies in developing the hardware-software interfaces.

Our typology of spin-off/start-up firms presumes that firms that are both sponsored by the university and experience decentralized idea development are rare, and accordingly we only encountered one example in our sample that fits this conception: a firm providing customer-relationship management software. Since it was founded, the firm was acquired several times by systems-management firms as part of a broader trend 
of consolidation in the industry, but remained functional and performed similar operations with the same core intellectual property as at the time of inception. The firm's original intellectual property was developed within an independent research organization, i.e. the Waterloo Foundation for the Advancement of Computing (WATFAC), which was created and funded by University of Waterloo faculty who had a stake in a successful spin-off firm prior to this engagement. Before the firm was spun off from WATFAC, it was housed in space leased by WATFAC from the university, which unofficially provided support facilities such as a communication system. The spin-off from WATFAC, in part, occurred to formalize the relationship between the university and the fledgling firm. To further underline this relationship, most of the individuals who worked on developing the early intellectual property were graduates and co-op students at the University of Waterloo, and there was a great deal of interaction between the research foundation and the university. The support of the university was critical to the early development of the firm, but the intellectual property developed was funded by an entity that was technically separate from the university.

\subsection{Character of knowledge applied and co-localization of start-up founders}

In aggregate, the types of spin-off and start-up processes related to the University of Waterloo indicate a mixed structure: On the one hand, there is a larger group of more spontaneous, unsponsored start-up firms that have developed out of a loose relationship with the university (see, also, Steffensen et al. 2000). These firms were often formed in relation to an existing niche, and thus sometimes experienced difficulties in extending their market reach. Their growth trajectories were quite diverse, with most firms remaining small, while others that were subsequently acquired, stagnated in terms of their regional size. On the other hand, a second group of sponsored spin-off firms existed that were directly related to university research. These firms were probably among the most innovative, yet experienced difficulties in achieving market legitimacy (see Hannan and Freeman 1984), and thus also remained relatively small. The most successful were those firms that resulted from university-industry joint ventures.

To shed further light on the regional impacts and future prospects of universityrelated start-ups/spin-offs, Table 3 sets out a complementary typology set according to 
the characteristic of university knowledge applied (Pirnay et al. 2003; Hindle and Yencken 2004), and the nature of co-localization of the founders. As described above, this typology assumes that non-co-localized spin-offs/start-ups, based on generic knowledge, might initially have wider networks and market access in their early development (Mustar 1997); while ventures based on specialized knowledge might have a larger long-term growth potential if they succeed in achieving broad market legitimacy. ${ }^{19}$

In only one of the 18 firms investigated, it was not possible to trace back to a physical co-location of the founders prior to the firm's formation process within the region: RIM - Waterloo's most prominent start-up success in the IT field. As founder and co-CEO Mike Lazaridis emphasized many times, RIM is not a classical spin-off from university research. In fact, Lazaridis, who was a student at the University of Waterloo, dropped out before receiving his Bachelor of Engineering to form RIM as a consulting firm in 1984 (Colapinto 2007; Wahl 2007); their first contract was for General Motors. Early on, Lazaridis and his co-founder Fregin, who met and became friends in Windsor where they lived prior to their university education, began providing wireless point-ofsale systems (Gagné 2005). The firm developed its own radio transceivers and soon recognized the value of moving into the area of wireless technology, whereby they later began producing the line of products that is now known as the "Blackberry". In terms of the firm's research-based relationship to the University of Waterloo, it appears relatively weak. Lazaridis repeatedly pointed out that the flow of new graduates would be the most important source of technology transfer from the local universities (Brady 2004; Livingston 2007; Fielding 2008).

RIM's non-co-localization supports the hypothesis that such a configuration can stimulate immediate wider access to new markets and a boost in sales, which was also exemplified by another firm in our sample, although not in its original start-up phase. This specific venture produces natural language search and database systems with customer service applications, and the Waterloo-based division of the firm initially focused on providing support to university clients. A CEO was hired, who originated

\footnotetext{
${ }^{19}$ While non-co-localization could only be tested in cases where there were two or more founders involved in the start-up process, the type of knowledge that led to the development of a firm's initial core technology was evaluated in each case.
} 
from Toronto, and, parallel to this, operations were established in Toronto. Management, sales, development, and customer support activities remained located at both locations. Through hiring the CEO from Toronto, the firm was able to extend its business quickly to the financial sector, including several banks headquartered in the Greater Toronto Area.

In all other cases, co-founders were previously co-located in the region, either living, working, and/or studying there, suggesting that only a few firms benefited from immediate access to otherwise geographically and socially unconnected networks of market contacts. While the typology set out in the beginning possibly attributes the highest regional impact and growth potential to firms where the founders are not colocalized and, at the same time, draw on a specific knowledge base, a clear example was not found in our sample, which corresponds with this description. Access to knowledge pools in other regions was mentioned by the interviewees and considered as an important source for innovation, but this was typically established in the context of later collaborations, rather than in the initial firm formation.

Almost two thirds of all firms in the sample relied on generic, broad knowledge inputs in the development of their initial core product, which they largely obtained either through university education or working experiences in the region. In contrast, about one third of the firms were founded utilizing a core technology, which was developed with specific knowledge inputs emanating from the university's core competencies in particular technology fields. The classification of spin-offs according to the character of the university knowledge applied, illustrates that sponsored spin-off/start-up firms, regardless of whether they were based on inputs from university research or from university-industry joint ventures for the development of innovations, generally relied on specific knowledge inputs. Conversely, the majority of unsponsored firms in our sample (10 out of 11 firms) described generic broad knowledge inputs as the foundation for their initial product development.

\section{Conclusions}

This study set out with the goal of responding to the need to develop a wider practical typology of university spin-offs/start-ups that first emphasizes the role of knowledge linkages, second provides a regional analysis, and third adopts a dynamic perspective. 
The proposed taxonomy of university spin-off/start-up firms, which was subsequently tested in our regional case study, is effective in scrutinizing the different roles a local university plays in supporting firm formation processes of various types of new ventures, and how they progress over time. It allows us to evaluate the wider regional impact of university-related start-up and spin-off phenomena by, for instance, developing scenarios regarding the growth potential of these firms. The case study conducted has been quite informative for two reasons: On the one hand, it has illustrated the usefulness of our typology and demonstrated how it can be fruitfully applied in a regional context. On the other hand, this case has enabled us to investigate the role of university spin-offs/start-ups in regional growth and modernization processes, and to some degree 'de-mystify' the role the University of Waterloo has played in the Kitchener and Guelph metropolitan areas.

The University of Waterloo is clearly a significant local source for innovation within this region, but only played a role in the formation process of about half of the firms interviewed. Eight of the 18 firms can be classified as unsponsored, decentralized start-ups, which did not derive their technological competence from specialized university research or university-industry joint ventures. The remaining 10 firms in the sample received, or utilized, at least some level of inputs or resources from the University of Waterloo that were, to a varying degree, important in the processes of establishing the business. Interestingly, a number of firms, which originally spun off from universitygenerated research, had relatively little input or stimulus from the university later on. At the same time, some unsponsored decentralized ventures considered the university as a vital element in their development, despite not having received support at the time the firm was established.

The typology of spin-offs/start-ups put forward (Tables 1 and 2) and the subsequent categorization of our sample firms (Table 4) clearly illustrate several important trends: First, sponsored spin-offs are the result of particular university research activities. They apply specific knowledge inputs in the development of their initial core technology. Second, unsponsored spin-offs that have their foundation in decentralized idea development outside the university setting strongly rely on broad generic knowledge in the development of innovative products. Overall, it is surprising that even the firms that received some kind of direct university support described the role of the university as relatively limited. Our survey also shows that once there were multiple firm founders, 
they were usually co-localized in the region, regardless of what type of knowledge was utilized.

It would be difficult to make predictions regarding the growth potential of the individual university spin-off/start-up firms, as the firms vary significantly in age, level of specialization, and the resulting prospective market size. Interestingly, however, the non-co-localized spin-off type, which has a great potential to achieve wider market legitimacy in the start-up stage, occurred only as an exception in our sample population. Nevertheless, the vibrant merger and acquisition activities that have become apparent in this research indicate that many of the ventures have the capacity to attract the interest of other regional, national, or international firms, and, through this, stimulated growth in the regional IT sector. Employment levels and growth performance related to the spin-off process have, however, remained modest in many firms. Therefore, it seems premature to over-emphasize regional economic successes, and celebrate the development of a "post-industrial Waterloo" related to university-driven ventures (Perry 2009).

A narrow definition of spin-offs, which would focus on firms that are the result of direct university funding and specialized university research, would deem the suggested typology of ventures unnecessary. However, there are several arguments as to why our revised typology of university spin-off/start-up firms is particularly useful. Above all, unsponsored spin-offs based on decentralized idea development represent a significant portion of start-up businesses (almost half of all firms), and are unlikely to exist without the university. They benefit from regional research capacities and the advanced education of their technical staff in the generation of innovative products. Overlooking this group of university-related start-ups and their association with the university would eliminate a significant segment of high-tech ventures from the analysis. Considering that it is the collective of high-tech firms, which are commonly acknowledged in the literature as the key drivers of economic change and growth, all suggested categories of spinoffs/start-ups need to be included in a study that investigates the regional economic impact of a university. Firms that fall into the category of having modest or weak university involvement in their start-up process can provide important insights into a local university's competencies in research and teaching, and how these benefit the local economy, rather than solely emphasizing and evaluating its ability to transfer technology 
and initiate firm formation processes in a linear mode through university research projects.

\section{Acknowledgements}

Parts of this paper were presented in November 2008 at the Annual Fall Meeting of the Ontario Network on the Regional Innovation System (ONRIS) in Toronto, and in May 2009 at the Annual Meetings of the Canadian Association of Geographers in Ottawa. We would like to thank Derrek Eberts, Iain Wallace, Mike Wright, and the participants of these meetings for providing critical comments, and Nicole Kogler for a superb editing job. Thanks are also due to the Social Sciences and Humanities Research Council of Canada for providing financial support for this research.

\section{References}

Aggarwal, R. and Bayus, B. L. (2002): The market evolution and sales takeoff of product innovations. Management Science 48 (8): 1024-1041.

Allaby, I. (1984): The not so hallowed halls of higher learning. Canadian Business 57 (9): 85-89.

Arrow, K. (1962): Economic welfare and the allocation of resources for invention. In: Nelson, R. (ed.): The Rate and Direction of Inventive Activity: Economic and Social Factors. Princeton: Princeton University Press, pp. 609-625.

Audretsch, D. V., Lehmann, E. E. and Warning, S. (2005): University spillovers and new firm location. Research Policy 34 (7): 1113-1122.

Autio, E. and Lumme, A. (1998): Does the innovator role affect the perceived potential for growth? Analysis of four types of new technology-based firms. Technology Analysis \& Strategic Management 10: 41-54.

Bathelt, H. (1991): Schlüsseltechnologie-Industrien: Standortverhalten und Einfluß auf den regionalen Strukturwandel in den USA und in Kanada (Key Technology Industries: Location Behaviour and Impact on Regional Change in the USA and Canada). Berlin, Heidelberg, New York: Springer. 
Bathelt, H. and Hecht, A. (1990): Key technology industries in the Waterloo region: Canada's Technology Triangle (CTT). Canadian Geographer 34: 225-234.

Bercovitz, J. and Feldman, M. P. (2006): Entrepreneurial universities and technology transfer: a conceptual framework for understanding knowledge-based economic development. Journal of Technology Transfer 31 (1): 175-188.

Black, D. (1988): Canada's Technology Triangle. En Route (August): 30-32, 44, 46 and 52.

Boardman, P. C. and Ponomariov, B. L. (2009): University researchers working with private companies. Technovation 29: 142-153.

Bower, D. (2003): Business model fashion and the academic spinout firm. $R \& D$ Management 33 (2): 97-105.

Brady, D. (2004): RIM's Lazaridis. Interview with Mike Lazaridis. Business Week Online (URL: http://www.businessweek.com/magazine/content/04_16/b3879097.htm, date accessed April 27, 2008).

Bramwell, A., Nelles, J. and Wolfe, D. A. (2008): Knowledge, innovation and institutions: global and local dimensions of the ICT cluster in Waterloo, Canada. Regional Studies 42: 101-116.

Bramwell, A. and Wolfe, D. A. (2008): Universities and regional economic development: the entrepreneurial University of Waterloo. Research Policy 37 (8): 1175-1187.

Callan, B. (2001): Generating spin-offs: evidence from the OECD. Science Technology Industry Review 26: 13-56.

Chesbrough, H. and Rosenbloom, R. S. (2002): The role of business model in capturing value from innovation. Industrial and Corporate Change 11 (3): 529-544.

Chiesa, V. and Piccaluga, A. (2000): Exploitation and diffusion of public research: the general framework and the case of academic spin-off companies. $R \& D$ Management 30: 329-340.

Clarysse, B., Wright, M., Lockett, A., van de Velde, E. and Vohora, A. (2005): Spinning out new ventures: a typology of incubation strategies from European research institutions. Journal of Business Venturing 20 (2): 183-216.

Colapinto, C. (2007): A Way to Foster Innovation: A Venture Capital District. From Silicon Valley and Route 128 to Waterloo Region. Working Paper no. 2007-24. 
Dipartimento Di Scienze Economiche Aziendale e Statistiche, Universita Degli Studi Di Milano (URL: http://www.economia.unimi.it/uploads/wp/Colapinto2007 24.pdf, date accessed March 23, 2008).

Communitech (2006): State of the Industry - Technology in the Waterloo Region: Report 2006. Waterloo.

Cooper, A. C. (1971): Spin-offs and technical entrepreneurship. IEEE Transactions on Engineering Management 18: 2-6.

DiGregorio, D. and Shane, S. (2003): Why do some universities generate more start-ups than others? Research Policy 32 (2): 209-27.

Djokovic, D. and Souitaris, V. (2008): Spinouts from academic institutions: a literature review with suggestions for further research. Journal of Technology Transfer 33: 225-247.

Druilhe, C. and Garnsey, E. (2004): Do academic spin-outs differ and does it matter? Journal of Technology Transfer 29 (3-4): 269-285.

Etzkowitz, H., Webster, A., Gebhardt, C. and Terra, B. R.C. (2000): The future of the university and the university of the future: evolution of ivory tower to entrepreneurial paradigm. Research Policy 29 (2): 313-330.

Fielding, D. (2008): Leaps of faith. Globe and Mail, Report on Business 24 (10): 44-49.

Fischer M. M. and Varga A. (2003): Spatial knowledge spillovers and university research: evidence from Austria. Annals of Regional Science 37 (2):303-322.

Fontes, M. (2005): Distant networking: the knowledge acquisition strategies of 'outcluster' biotechnology firms. European Planning Studies 13 (6): 899-920.

Fujita, M. and Thisse, J.-F. (1996): Economics of agglomeration. Journal of the Japanese and International Economies 10: 339-378.

Gagné, C. (2005): Douglas Fregin - the other RIM guy. Canadian Business, December 5.

Garvin, D. A. (1983): Spin-offs and the new firm formation process. California Management Review 25: 3-20.

Hannan, M. T. and Freeman, J. (1984): Structural inertia and organizational change. American Journal of Sociology 49: 149-164.

Hayter, R. (1997): The Dynamics of Industrial Location: The Factory, the Firm and the Production System. Chicester, New York: Wiley. 
Hindle, K. and Yencken, J. (2004): Public research commercialisation, entrepreneurship and new technology based firms: an integral model. Technovation 24: 793-803.

Kenney, M. and Patton, D. (2005): Entrepreneurial geographies: support networks in three high-technology industries. Economic Geography 81: 201-228.

Landström, H. (2005): Pioneers in Entrepreneurship and Small Business Research. New York: Springer.

Livingston, J. (2007): Founders at Work: Stories of Startups’ Early Days. NewYork: Apress.

Maskell, P. and Malmberg, A. (1999): The competitiveness of firms and regions: 'ubiquitification' and the importance of localized learning. European Urban and Regional Studies 6: 9-25.

McAdam, M. and McAdam, R. (2008): High tech start-ups in University Science Park incubators: the relationship between the start-up's lifecycle progression and use of the incubator's resources. Technovation 28: 277-290.

McQueen, D. H. and Wallmark, J. T. (1982): Spin-off companies from Chalmers University of Technology. Technovation 1: 305-315.

Moray, N. and Clarysse, B. (2005): Institutional change and resource endowments to science-based entrepreneurial firms. Research Policy 34 (7): 1010-1027.

Mossig, I. (2000): Räumliche Konzentration der Verpackungsmaschinenbau-Industrie in Westdeutschland: Eine Analyse des Gründungsgeschehens (Spatial Concentration of the Packaging Machinery Industry in West Germany: An Analysis of Firm Formation Processes). Münster: Lit.

Mustar, P. (1997): Spin-off enterprises: how French academics create hi-tech companies: the conditions for success or failure. Science and Public Policy 24: 37-43.

Mustar, P., Renault, M., Colombo, M. G., Piva, E., Fontes, M., Lockett, A., Wright, M., Clarysse, B. and Moray, N. (2006): Conceptualising the heterogeneity of research-based spin-offs: a multi-dimensional taxonomy. Research Policy 35 (2): 289-308.

Ndonzuau, F. N., Pirnay, F. and Surlemont, B. (2002): A stage model of academic spinoff creation. Technovation 22 (5): 281-289

Nelson, R. R. (1959): The simple economics of basic scientific research. Journal of Political Economy 67: 297-306. 
Nicolaou, N. and Birley, S. (2003): Academic networks in a trichotomous categorisation of university spinouts. Journal of Business Venturing 18 (3): 333-359.

Niosi, J. (2000): Canada’s National System of Innovation. Montreal, Kingston: McGillQueen's University Press.

Open Text Corporation (2001): Ten Years of Innovation: 1991 - 2001. Waterloo, ON: Open Text Corporation.

Parker, P. (2001): Local-global partnerships for high-tech development: integrating topdown and bottom-up models. Economic Development Quarterly 15: 149-167.

Perry, A. (2009): Meet our post-industrial Waterloo. Toronto Star, March 21, p. B2.

Pirnay, F., Surlemont, B. and Nlemvo, F. (2003): Towards a typology of university spinoffs. Small Business Economics 21: 355-369.

PricewaterhouseCoopers (2001a): Waterloo Region/Canada's Technology Triangle 2001: Techmap. Waterloo.

PricewaterhouseCoopers (2001b): University of Waterloo: Regional Economics Benefits Study. Waterloo.

Pries, F. and Guild, P. (2007): Commercial exploitation of new technologies arising from university research: start-ups and markets for technology. R\&D Management 37: 319-328.

Rappert, B., Webster, A. and Charles, D. (1999): Making sense of diversity and reluctance: academic-industrial relations and intellectual property. Research Policy 28: 873-890.

Rasmussen, E., Moen, Ø. and Guldbransen, M. (2006): Initiatives to promote commercialization of university knowledge. Technovation 26: 518-533.

Rasmussen, E. (2008): Government instruments to support the commercialization of university research: lessons from Canada. Technovation 28: 506-517.

Roberts, E. B. (1968): Entrepreneurship and technology: a basic study of innovators; how to keep and capitalize on their talents. Research Management 11: 249-266.

Roberts, E. B. (1991): Entrepreneurs in High Technology: Lessons from MIT and Beyond. Oxford: Oxford University Press.

Rogers, E. M. (1986): The role of the research university in the spin-off of hightechnology companies. Technovation 4: 169-181. 
Rothaermel, F. T., Agung, S. D. and Jiang, L. (2007): University entrepreneurship: taxonomy of the literature. Industrial and Corporate Change 16 (4): 691-791.

Saxenian, A. (1994): Regional Advantage: Culture and Competition in Silicon Valley and Route 128. Cambridge, MA: Harvard University Press.

Smilor, R. W., Gibson, D. V. and Dietrich, G. B. (1990): University spin-out companies: technology start-ups from UT Austin. Journal of Business Venturing 5 (1): 63-76.

Stam, E. (2007): Why butterflies don't leave: locational behavior of entrepreneurial firms. Economic Geography 83: 27-50.

Steffensen, M., Rogers, E. and Speakman, K. (2000): Spin-offs from research centers at a research university. Journal of Business Venturing 15 (1): 93-111.

Stinchcombe, A. L. (1965): Social structures and organizations. In: March, J. G. (ed.): Handbook of Organizations. Chicago: Rand-McNally, pp. 142-193.

Stuart, T.E., Hoang, H. and Hybels, R. C. (1999): Interorganizational endorsements and the performance of entrepreneurial ventures. Administrative Science Quarterly 44: 315-349.

Vohora, A., Wright, M. and Lockett, A. (2004): Critical junctures in the growth in university high-tech spinout companies. Research Policy 33: 147-175.

Wahl, A. (2007): Innovation station. Canadian Business, October 8.

Wright, M., Birley, S. and Mosey, S. (2004): Entrepreneurship and university technology transfer. Journal of Technology Transfer 29: 235-246.

Xu, S. X. (2003): Knowledge Transfer, Inter-Firm Networking and Collective Learning in High Technology Cluster Evolution: A Network Analysis of Canada's Technology Triangle. Master Thesis. Waterloo: University of Waterloo.

Zahra, S. A., Van de Velde, E. and Larrañeta, B. (2007): Knowledge conversion capability and the performance of corporate and university spin-offs. Industrial and Corporate Change 16 (4): 569-608.

Zook, M. A. (2002): Grounded capital: venture financing and the geography of the Internet industry, 1994-2000. Journal of Economic Geography 2: 151-177. 
Table 1. Typology of spin-offs and start-ups according to university sponsorship and involvement in firm formation processes

\begin{tabular}{|c|c|c|c|}
\hline \multirow{3}{*}{$\begin{array}{l}\text { University } \\
\text { sponsorship }\end{array}$} & \multicolumn{3}{|c|}{ University involvement in spin-off and start-up processes } \\
\hline & \multicolumn{2}{|c|}{ UNIVERSITY SPIN-OFFS } & \multirow{2}{*}{$\begin{array}{l}\text { UNIVERSITY-RELATED } \\
\text { START-UPS } \\
\text { Decentralized idea } \\
\text { development }\end{array}$} \\
\hline & University research & $\begin{array}{l}\text { University-industry } \\
\text { joint ventures }\end{array}$ & \\
\hline $\begin{array}{l}\text { Sponsored } \\
\text { spin-offs }\end{array}$ & $\begin{array}{l}\text { Intellectual property } \\
\text { (IP) development at } \\
\text { the university } \\
\text { through publicly } \\
\text { funded research } \\
\text { grants; as a part of } \\
\text { standard university } \\
\text { operations }\end{array}$ & $\begin{array}{l}\text { Formal development } \\
\text { agreement between } \\
\text { university and industry; } \\
\text { typically involves } \\
\text { preferential licensing } \\
\text { rights for IP that the } \\
\text { research generates for } \\
\text { the sponsoring firm }\end{array}$ & $\begin{array}{l}\text { Firms started by former } \\
\text { graduates or } \\
\text { undergraduate students } \\
\text { after they finish school; } \\
\text { might have developed a } \\
\text { business idea from their } \\
\text { joint classroom } \\
\text { experience }\end{array}$ \\
\hline $\begin{array}{l}\text { Unsponsored } \\
\text { spin-offs }\end{array}$ & $\begin{array}{l}\text { Researcher develop } \\
\text { an idea within the } \\
\text { university; pay for } \\
\text { the IP and then leave } \\
\text { the university to } \\
\text { develop it further; } \\
\text { possibly without } \\
\text { support of the } \\
\text { university }\end{array}$ & $\begin{array}{l}\text { Off-site, unsolicited } \\
\text { innovation brought } \\
\text { forward by someone in } \\
\text { the research group and } \\
\text { developed into a } \\
\text { product; possibly an } \\
\text { ancillary development } \\
\text { not central to the study } \\
\text { or research project that } \\
\text { is subsequently } \\
\text { developed }\end{array}$ & $\begin{array}{l}\text { Completely self- } \\
\text { developed firms; } \\
\text { principals meet } \\
\text { informally, off-site or } \\
\text { outside campus } \\
\text { academic facilities but } \\
\text { have social ties with the } \\
\text { university; typically the } \\
\text { university is not aware } \\
\text { of these processes }\end{array}$ \\
\hline
\end{tabular}


Table 2. Typology of start-ups according to the character of university knowledge applied and co-localization of the founders

\begin{tabular}{|c|c|c|}
\hline \multirow{2}{*}{$\begin{array}{l}\text { Character of } \\
\text { university } \\
\text { knowledge } \\
\text { applied }\end{array}$} & \multicolumn{2}{|c|}{ Co-localization of start-up founders } \\
\hline & Co-localized & Not co-localized \\
\hline $\begin{array}{l}\text { Generic, } \\
\text { broad } \\
\text { knowledge }\end{array}$ & $\begin{array}{l}\text { Broad epistemic knowledge, } \\
\text { largely based on the capabilities } \\
\text { and focus of the local incubator } \\
\text { university; limited potential for } \\
\text { innovation }\end{array}$ & $\begin{array}{l}\text { Broad epistemic knowledge } \\
\text { drawing from a wider set of } \\
\text { experiences at different places; } \\
\text { innovation benefits from broader } \\
\text { access to generic knowledge pools }\end{array}$ \\
\hline $\begin{array}{l}\text { Specific } \\
\text { knowledge }\end{array}$ & $\begin{array}{l}\text { Drawing on specific knowledge in } \\
\text { the university's competencies, } \\
\text { including tacit knowledge pools } \\
\text { (particularly in dynamic } \\
\text { technology fields) }\end{array}$ & $\begin{array}{l}\text { Drawing from different specific } \\
\text { knowledge pools (e.g., different } \\
\text { research projects/specializations); } \\
\text { large potential for innovation; } \\
\text { access to different specialized } \\
\text { regional knowledge pools }\end{array}$ \\
\hline
\end{tabular}


Table 3. University-related start-up/spin-off firms in the Kitchener/Guelph metropolitan areas

\begin{tabular}{|c|c|c|c|c|}
\hline Firm category & $\begin{array}{l}\text { University- } \\
\text { related start-ups } \\
\text { (number) }\end{array}$ & $\begin{array}{c}\text { University of } \\
\text { Waterloo spin- } \\
\text { offs } \\
\text { (number) }\end{array}$ & $\begin{array}{c}\text { University of } \\
\text { Guelph spin- } \\
\text { offs } \\
\text { (number) }\end{array}$ & $\begin{array}{c}\text { Total } \\
\text { (number) }\end{array}$ \\
\hline \multicolumn{5}{|c|}{ - A. Sectoral split-up - } \\
\hline - All firms & 227 & 47 & 14 & $288(100.0 \%)$ \\
\hline - Non-IT firms & 133 & 23 & 13 & $169(58.7 \%)$ \\
\hline - IT firms & 94 & 24 & 1 & $119(41.3 \%)$ \\
\hline \multicolumn{5}{|c|}{ - B. IT firm status/trajectory - } \\
\hline - IT firms & 94 & 24 & 1 & $119(100.0 \%)$ \\
\hline $\begin{array}{l}\text { - Firms } \\
\text { confirmed } \\
\text { closed }\end{array}$ & 14 & 3 & 0 & $17(14.3 \%)$ \\
\hline $\begin{array}{l}\text { - Firms not } \\
\text { found }\end{array}$ & 16 & 0 & 0 & $16(13.4 \%)$ \\
\hline $\begin{array}{l}\text { - Firms not in } \\
\text { region }\end{array}$ & 30 & 6 & 0 & $36(30.3 \%)$ \\
\hline $\begin{array}{l}\text { - Firms acquired } \\
\text { by other } \\
\text { regional IT } \\
\text { firms }\end{array}$ & 6 & 2 & 0 & $8(6.7 \%)$ \\
\hline $\begin{array}{l}\text { - Relevant IT } \\
\text { firm population }\end{array}$ & 28 & 13 & 1 & $42(35.3 \%)$ \\
\hline \multicolumn{5}{|c|}{ - C. Sample statistics - } \\
\hline $\begin{array}{l}\text { Relevant } \\
\text { population }(\mathrm{N})\end{array}$ & 28 & 13 & 1 & $42(100.0 \%)$ \\
\hline Contacted firms & 24 & 8 & 0 & $32(76.2 \%)$ \\
\hline Rejections & 11 & 3 & 0 & $14(33.3 \%)$ \\
\hline Interviews & 13 & 5 & 0 & $18(42.9 \%)$ \\
\hline
\end{tabular}


Table 4. Economic indicators of the sampled IT-related University of Waterloo spin-off/start-up firms, 2008

\begin{tabular}{|c|c|c|c|c|c|c|c|c|c|c|c|}
\hline $\begin{array}{l}\text { Inter- } \\
\text { view } \\
\text { no. }\end{array}$ & $\begin{array}{l}\text { Date } \\
\text { estab- } \\
\text { lished }\end{array}$ & $\begin{array}{l}\text { Owner } \\
\text {-ship }\end{array}$ & $\begin{array}{l}\text { Products/ } \\
\text { services }^{1)}\end{array}$ & $\begin{array}{l}\text { Regional } \\
\text { emp- } \\
\text { loyees }\end{array}$ & $\begin{array}{l}\text { Share of } \\
\text { regional } \\
\text { supplies }\end{array}$ & $\begin{array}{l}\text { Region } \\
\text {-al } \\
\text { sales }\end{array}$ & $\begin{array}{l}\quad \text { Share } \\
\text { Other } \\
\text { Canadian } \\
\text { sales }\end{array}$ & $\begin{array}{l}\text { f sales } \\
\text { US } \\
\text { sales }\end{array}$ & $\begin{array}{l}\text { Other } \\
\text { inter- } \\
\text { national } \\
\text { sales }\end{array}$ & $\begin{array}{l}\text { University sponsorship and } \\
\text { involvement in firm formation } \\
\text { processes (see Table 1) }\end{array}$ & $\begin{array}{l}\text { University knowledge applied and } \\
\text { co-localization of the founders (see } \\
\text { Table 2) }\end{array}$ \\
\hline 1 & 1991 & Public & Software & 250 & $5 \%$ & $\mathrm{n} / \mathrm{a}^{2)}$ & $\mathrm{n} / \mathrm{a}$ & $\mathrm{n} / \mathrm{a}$ & $\mathrm{n} / \mathrm{a}$ & Unsponsored / Decentralized & Generic knowledge / Co-localized \\
\hline 2 & 1977 & Public & Software & 84 & $<1 \%$ & $1 \%$ & $1 \%$ & $60 \%$ & $40 \%$ & Unsponsored / Decentralized & Generic knowledge / Co-localized \\
\hline 3 & 1981 & Private & Instruments & 145 & $20 \%$ & $1 \%$ & $13 \%$ & $37 \%$ & $48 \%$ & $\begin{array}{l}\text { Unsponsored / University-industry } \\
\text { joint venture }\end{array}$ & Generic knowledge / Co-localized \\
\hline 4 & 1991 & Public & Software & 9 & $<1 \%$ & $\mathrm{n} / \mathrm{a}$ & $\mathrm{n} / \mathrm{a}$ & $\mathrm{n} / \mathrm{a}$ & $\mathrm{n} / \mathrm{a}$ & Sponsored / Decentralized & Generic knowledge / Co-localized \\
\hline 5 & 1997 & Private & Software & 5 & $\mathrm{n} / \mathrm{a}$ & $\mathrm{n} / \mathrm{a}$ & $\mathrm{n} / \mathrm{a}$ & $\mathrm{n} / \mathrm{a}$ & $\mathrm{n} / \mathrm{a}$ & Unsponsored / Decentralized & Generic knowledge / Co-localized \\
\hline 6 & 1984 & Private & Software & 65 & $<1 \%$ & $1 \%$ & $9 \%$ & $40 \%$ & $50 \%$ & $\begin{array}{l}\text { Sponsored / University-industry } \\
\text { joint venture }\end{array}$ & Specific knowledge / Co-localized \\
\hline 7 & 1991 & Public & Software & 12 & $<1 \%$ & $2 \%$ & $13 \%$ & $60 \%$ & $25 \%$ & $\begin{array}{l}\text { Unsponsored / University- } \\
\text { developed }\end{array}$ & Generic knowledge / Co-localized \\
\hline 8 & 1984 & Private & Software & 6 & $10 \%$ & $5 \%$ & $85 \%$ & $5 \%$ & $5 \%$ & $\begin{array}{l}\text { Unsponsored / University- } \\
\text { developed }\end{array}$ & Generic knowledge / Co-localized \\
\hline 9 & 1989 & Public & Software & 400 & $<1 \%$ & $0 \%$ & $3 \%$ & $45 \%$ & $52 \%$ & $\begin{array}{l}\text { Sponsored / University-industry } \\
\text { joint venture }\end{array}$ & Specific knowledge / Co-localized \\
\hline 10 & 1976 & Private & Software & 5 & $<1 \%$ & $0 \%$ & $10 \%$ & $70 \%$ & $20 \%$ & Sponsored / University-developed & Specific knowledge / Co-localized \\
\hline 11 & 1976 & Private & Consulting & 450 & $<1 \%$ & $0 \%$ & $15 \%$ & $25 \%$ & $60 \%$ & Unsponsored / Decentralized & Generic knowledge / Co-localized \\
\hline 12 & 1988 & Private & Software & 150 & $<1 \%$ & $0 \%$ & $6 \%$ & $54 \%$ & $40 \%$ & Sponsored / University-developed & Specific knowledge / Co-localized \\
\hline 13 & 1980 & Public & $\begin{array}{l}\text { Semi- } \\
\text { conductors }\end{array}$ & 255 & $10 \%$ & $1 \%$ & $3 \%$ & $30 \%$ & $66 \%$ & Sponsored / University-developed & Specific knowledge / Co-localized \\
\hline 14 & 1984 & Public & $\begin{array}{l}\text { Comm- } \\
\text { unication }\end{array}$ & 5200 & $<1 \%$ & $0 \%$ & $7 \%$ & $60 \%$ & $33 \%$ & Unsponsored / Decentralized & $\begin{array}{l}\text { Generic knowledge / Not Co- } \\
\text { localized }\end{array}$ \\
\hline 15 & 1988 & Public & Engineering & 3 & $100 \%$ & $98 \%$ & $1 \%$ & $0 \%$ & $1 \%$ & Unsponsored / Decentralized & Generic knowledge / Co-localized \\
\hline 16 & 1998 & Public & $\begin{array}{l}\text { Semi- } \\
\text { conductors }\end{array}$ & 45 & $<1 \%$ & $0 \%$ & $0 \%$ & $0 \%$ & $100 \%$ & Unsponsored / Decentralized & Specific knowledge / Co-localized \\
\hline 17 & 2004 & Private & Software & 39 & $<1 \%$ & $0 \%$ & $50 \%$ & $20 \%$ & $30 \%$ & Sponsored / University developed & Specific knowledge / Co-localized \\
\hline 18 & 2000 & Private & Software & 20 & $10 \%$ & $1 \%$ & $20 \%$ & $70 \%$ & $10 \%$ & Unsponsored / Decentralized & Generic knowledge / Co-localized \\
\hline
\end{tabular}


